\title{
Climate change dominates recent sedimentation and organic carbon burial in Lake Chenghai, southwest China
}

\author{
Weiwei SUN, ${ }^{1 \#}$ Qingfeng JIANG, ${ }^{2 \#}$ Enfeng LIU, ${ }^{3}$ Jie CHANG, ${ }^{1}$ Enlou ZHANG ${ }^{1 *}$ \\ ${ }^{1}$ State Key Laboratory of Lake Science and Environment, Nanjing Institute of Geography and Limnology, Chinese Academy of Sciences, \\ Nanjing 210008; ${ }^{2}$ School of Geography Sciences, Nantong University, Nantong, Jiangsu 226007; ${ }^{3}$ College of Geography and \\ Environment, Shandong Normal University, Jinan 250014, China \\ "Both authors contributed equally \\ *Corresponding author: elzhang@niglas.ac.cn
}

\begin{abstract}
Lacustrine ecosystems are directly influenced by terrestrial soil erosion, and excessive sediment loading constitutes a significant and widespread environmental issue. In order to investigate the response of catchment soil erosion and organic carbon burial to climate change and human activity, a sediment core spanning the last 160 years was retrieved from Lake Chenghai in southwest China. Multi-proxy analysis including grain-size composition and geochemical indicators were undertaken in this study. The result of grain-size vs. standard deviation method shows that the sensitive component with a modal size of $13.2 \mu \mathrm{m}$ is related to fluvial processes and sensitive to the catchment soil erosion. The increasing intensity of soil erosion was mainly determined by the weakening of Indian summer monsoon and global warming, as well as intensive human activities during the middle of $20^{\text {th }}$ century, which resulted in decreasing vegetation cover in Lake Chenghai catchment. The organic carbon burial rate was also attributed to the catchment disturbance, indicating that increased catchment soil erosion may impact the terrestrial carbon recycling.
\end{abstract}

Key words: Soil erosion; lacustrine sediment; climate change; human activity; carbon burial.

Received: January 2018. Accepted: May 2018.

\section{INTRODUCTION}

Lakes are vital ecosystems of great economic, cultural, scientific and educational values (Dudgeon et al., 2006). Despite the small fraction of the surface of the Earth occupied by lakes, they play an important role in climate system, by exchanging heat and water with the atmosphere and affecting the global carbon cycle (Krinner, 2003; Cole et al., 2007; Tranvik et al., 2009). In recent years, intense human activity and climate change have exerted significant effects on the freshwater ecosystems, environmental problems such as siltation, eutrophication, loss of biodiversity and degradation of ecological function (Liu and Diamond, 2005; Dudgeon et al., 2006; Vanmaercke et al., 2015). Because long-term monitoring records of water quality and ecological evolution are scarce in the world, palaeolimnology is crucial for understanding how lacustrine ecosystem response to past disturbance and evolutional processes (Dearing et al., 2006; Seddon et al., 2014).

Sediment accumulation rate (SAR), is a fundamental parameter of lacustrine sedimentary processes, affecting lake morphology, stratification, nutrient dynamics and assemblages of aquatic flora and fauna (Rose et al., 2011; Zhang et al., 2013). Previous studies often relate the changes of SAR to soil erosion in the catchment, especially land use and land cover changes caused by human activity (Liu et al., 2007; Rose et al., 2011; Xue and Yao, 2011; Xu et al., 2017). However, less focus has been directed towards the influence of atmospheric dust and precipitation of autogenetic carbonates (Neff et al., 2008; Yu et al., 2015). Lacustrine varve characteristics and modern observations suggest that the atmospheric dust is also an important source of lacustrine sediment in middle latitudes of China (Chu et al., 2009; Liu et al., 2009; Xiao et al., 2012; Chen F. et al., 2013; Dietze et al., 2014). Furthermore, global warming and eutrophication could also play a direct role leading to increases in autochthonous sediments from increased productivity (Rose et al., 2011; Yu et al., 2015). Therefore, more studies are needed to assess the variations of soil erosion and different impacts of climatic and anthropogenic factors.

Terrigenous elements such as Al, Fe, K, and Ti have been used to estimate supply of siliciclastic materials of fluvial or aeolian origin in lacustrine sediments (Yancheva et al., 2007; Chen HF et al., 2013; Shen et al., 2013; Zhang E. et al., 2017). Among these, Al, Fe, and $\mathrm{K}$ are not necessarily good indicators of sedimentary terrigenous origins: the element $\mathrm{Fe}$ is often influenced by authigenic precipitation from Fe-Mn oxyhydroxides and pyrite under reducing conditions (Naeher et al., 2013); while $\mathrm{Al}$ and $\mathrm{K}$ in siliciclastic materials are sensitive to chemical 
weathering and greatly dependent on grain-size (Yang et $a l ., 2006)$. Therefore, Ti is more commonly applied as an efficient indicator of siliciclastic materials transported by seasonal rivers and to reconstruct soil erosion history in the catchment of lake (Shen et al., 2013; Zhang E. et al., 2017). Grain-size parameters of mineral sediment are closely related to changes in provenance, transporting mechanism and sedimentary process (Sun et al., 2002; Xiao et al., 2008; Dietze et al., 2012). Recently, the transport and deposition dynamics of the lacustrine sediments are well partitioned by many numerical methods, for example, the grain-size vs. standard deviation method (Sun et al., 2003; Chen F. et al., 2013), the Weibull function (Sun et al., 2002), the log-normal distribution function (Xiao et al., 2008), and eigenspace analysis (Dietze et al., 2012; Yu et al., 2016).

The Yunnan-Guizhou Plateau is a typical plateau mountain region in southwest China. It is also one of the Five Lake Regions of China, located in the southeast margin of the Qinghai-Tibetan Plateau. The area has a complex topography along with abundant precipitation in summer, and human activity has brought serious soil erosion (Barton et al., 2004). However, long-term information concerning soil erosion and siltation of lakes is limited in this region (Wang et al., 2011a; Wang et al., 2011b). Moreover, these studies did not take the atmospheric dust loading into consideration, leading to overestimation in the soil erosion flux, which could be misleading to understand the linkage of soil erosion, human activity and climate change. Lake Chenghai is located in the upper and middle reaches of the Jinsha River in Yunnan Province, where soil erosion has become a major concern for land management because it drastically reduces arable land and yields abundant sediment (Su et al., 2014). The objectives of this study are therefore to estimate the historical soil erosion and its implication for terrestrial carbon cycling for Lake Chenghai over the past 160 years using lacustrine deposits, and the coupling effects of climate change and human activity at the decadal timescale are also discussed.

\section{METHODS}

\section{Site description}

Lake Chenghai (Fig.1a, 26 $27^{\circ}-26^{\circ} 38^{\prime} \mathrm{N}, 100^{\circ} 38^{\prime}-$ $100^{\circ} 41^{\prime} \mathrm{E}, 1500 \mathrm{~m}$ above sea level) is located in Yongsheng County, Yunnan Province in southwest China. It is a tectonic depression lake formed during the early Pleistocene (Wang and Dou, 1998). The lake has a surface area of about $77 \mathrm{~km}^{2}$, a maximum depth of about $35 \mathrm{~m}$ with a mean depth of $20 \mathrm{~m}$, and the area of the catchment is 318 $\mathrm{km}^{2}$ (Wu et al., 2004). There are no perennial inlet or outflow streams in the catchment at present, only a tunnel was excavated to divert water from the Xianren River into Chenghai for reducing lake level in $1993 \mathrm{AD}$, and the lake water is slightly brackish and alkaline, mainly fed by precipitation and groundwater (Wang and Dou, 1998). The


Fig. 1. Lake location (a) and sampling site (b). 
lake is currently eutrophic and the phytoplankton population is dominated by cyanobacteria (Wu et al., 2004; Wan et al., 2005).

The region has a temperate climate with distinct dry and wet seasons. Mean annual precipitation is about 740 $\mathrm{mm}$, more than $90 \%$ of which falls from June to September influenced by the southwest summer monsoon (Wang and Dou, 1998). Between October and May, the region is dominated by the dry Tibetan High, preventing the influence of humid air masses. The mean annual air temperature is $13.5^{\circ} \mathrm{C}$ and the average annual evaporation is approximately $2040 \mathrm{~mm}$ (Wan et al., 2005). The lake basin is surrounded by mountains ranging from 2300$4000 \mathrm{~m}$ asl, with a broad valley to the south. Catchment bedrock mainly consists of basalt, sandstones, dolomite limestone and muddy shale, topsoil types include red earth and mountain red brown soil. Pinus yunnanensis forest and semi-humid evergreen broadleaved forest dominate the natural vegetation in the catchment, however, the land cover in the lower valley had been seriously disturbed by human activity in the $20^{\text {th }}$ century (Wu et al., 2004).

\section{Sample collection}

The sediment core was collected using an UWITEC gravity corer equipped with a PVC tube of $60-\mathrm{cm}$ in length and 6-cm in outer diameter at a water depth of 31.8 $\mathrm{m}$ in April 2012 (CH2012, $55 \mathrm{~cm}$, Fig. 1b, 26 33'29.4"N, $\left.100^{\circ} 39^{\prime} 6.7^{\prime \prime} \mathrm{E}\right)$. Inspection of the cores at the time of sample collection indicated intact recovery of the sediment-water interface. Core $\mathrm{CH} 2012$ was sectioned at $1.0-\mathrm{cm}$ interval in the field. Samples were sealed into polyethylene bags and stored in the cooler until they were returned to the laboratory.

\section{Laboratory analysis}

In the laboratory, samples were freeze-dried and weighed to calculate the dry bulk density, which is defined as dry mass per unit wet volume (Liu et al., 2000). For dating, the weighed dry samples were sealed in plastic test tubes with caps. Radionuclides $\left({ }^{210} \mathrm{~Pb},{ }^{226} \mathrm{Ra}\right.$ and $\left.{ }^{137} \mathrm{Cs}\right)$ activity in samples were measured using an ORTEC HPGe GWL series well-type coaxial low background intrinsic germanium detector. The unsupported ${ }^{210} \mathrm{~Pb}\left({ }^{210} \mathrm{~Pb}\right.$ ex $)$ in each sample was obtained by subtracting the activity of ${ }^{226} \mathrm{Ra}$ from the total activity of ${ }^{210} \mathrm{~Pb}$ (Appleby, 2001).

Before TOC and TN were measured using a Euro 3000 Elemental Analyzer, weighted samples were treated with $1 \mathrm{M} \mathrm{HCl}$ to remove carbonates, and then rinsed with de-ionized water and dried at $60^{\circ} \mathrm{C}$. The treated samples were ground and homogenized with an agate mortar. For the geochemistry analysis, the samples were homogenized in an agate mortar, and then completely digested by $\mathrm{HCl}-$ $\mathrm{HNO}_{3}-\mathrm{HF}-\mathrm{HClO}_{4}$ in Teflon beakers. The concentrations of major metals were determined using an inductively coupled plasma atomic emission spectrometer (ICPAES), the analytical data quality was assessed using analysis of reagent blanks, duplicate samples and standard reference materials (GBW07309) for each batch of samples. The concentrations of $\mathrm{Fe}, \mathrm{Ti}, \mathrm{Mn}$ and $\mathrm{P}$ are presented in this study.

All samples were subjected to grain-size analysis using a Malvern MS 2000 laser grain size analyzer ranging from 0.02 to $2000 \mu \mathrm{m}$ and yielding 100 pairs of grain-size data. Approximately $0.5 \mathrm{~g}$ of wet sediment was pretreated with $30 \% \mathrm{H}_{2} \mathrm{O}_{2}$ to remove organic matter and then with $10 \%$ $\mathrm{HCl}$ to remove carbonates. Subsequently, the samples were rinsed to a $\mathrm{pH}$ of about 7 , and the sample residue treated with $20 \mathrm{~mL}$ of $0.05 \mathrm{M}\left(\mathrm{NaPO}_{3}\right)_{6}$ and dispersed using an ultrasonic bath for $15 \mathrm{~min}$. Every sample was measured for three times and the mean was calculated and used for the analysis, and the measurement has an accuracy of $\pm 1 \%$. Grain size vs. standard deviation method was chosen to identify the sensitive terrestrial components within the lake setting (Sun et al., 2003). By applying the grain-size vs standard deviation method, the grain-size fraction with a high standard deviation can be regarded as the modal grainsize of an environmentally sensitive component. The component between the two adjacent low standard deviations is considered to be sensitive to a specific environment and depositional process (Sun et al., 2003).

All the laboratory analyses were performed at the State Key Laboratory of Lake Science and Environment, Nanjing Institute of Geography and Limnology, Chinese Academy of Sciences.

\section{Establishing the chronology and calculating sediment accumulation rate}

Estimation of accumulation rates from the radionuclides depth distributions documented for the individual cores requires the use of a model to establish the chronology or age-depth relationship for the core. The Constant Initial concentration (CIC) and the Constant Rate of Supply (CRS) models are the two most widely used ${ }^{210} \mathrm{~Pb}_{\text {ex }}$ dating models within lacustrine deposits (Appleby, 2001). CIC model assumes that the initial ${ }^{210} \mathrm{~Pb}_{\text {ex }}$ concentration from water to sediment was consistent through time. Under this scenario, the ${ }^{210} \mathrm{~Pb}_{\text {ex }}$ activity will decrease exponentially with mass depth $(z)$ due to the natural decay process. In contrast, the CRS model assumes that the supply of ${ }^{210} \mathrm{~Pb}_{\text {ex }}$ to the lacustrine sediment was constant, however, the accumulation rate could vary through time. The age $t$ at mass depth $z$ is estimated using this model as follows:

$t=\ln (\mathrm{A}(0) / \mathrm{A}(z)) / \lambda$

Where $\mathrm{A}(0)$ is the total ${ }^{210} \mathrm{~Pb}_{\text {ex }}$ inventory of the 
sediment core and $\mathrm{A}(z)$ is the total ${ }^{210} \mathrm{~Pb}_{\text {ex }}$ inventory in the sediment core below mass depth $z, \lambda$ is the ${ }^{210} \mathrm{~Pb}$ radioactive decay constant of 0.03114 .

However, the increase of organic matters, turbidity currents caused by flood and earthquake events might influence the supply rate of ${ }^{210} \mathrm{~Pb}_{\text {ex }}$ in lakes (Appleby 2001; Wan et al., 2005). When there are significant discrepancies between the results provided by the CRS model and ${ }^{137} \mathrm{Cs}$ chronostratigraphic markers, the peak of ${ }^{137} \mathrm{Cs}$ corresponding to the year 1963 can be incorporated into the CRS model as a composite CRS Model to improve the final result. The age $t$ of each sediment layer between the surface and marked layer and below the layer are calculated as equations (3) and (4), respectively:

$t=-\ln (1+\lambda *(\mathrm{~A}(0)-\mathrm{A}(z)) / P) / \lambda$

$t=\mathrm{T}_{0}-1963+\ln (\mathrm{A}(M) / \mathrm{A}(z)) / \lambda$

$P=-\lambda^{*}(\mathrm{~A}(0)-\mathrm{A}(M)) /\left(1-\mathrm{e}^{-\lambda(\mathrm{T} 0-1963)}\right)$

Where $\mathrm{T}_{0}$ is the sample year, $P$ is the mean ${ }^{210} \mathrm{~Pb}_{\mathrm{ex}}$ flux during the period between sample year and $1963, \mathrm{~A}(M)$ is the total ${ }^{210} \mathrm{~Pb}_{\text {ex }}$ inventory in the sediment core below marked layer corresponding to the year 1963.

The accumulation rate $R\left(\mathrm{~g} \mathrm{~m}^{-2} \mathrm{yr}^{-1}\right)$ and element (E) fluxes could be determined as follows:

$R=\Delta z / \Delta t * 10000$

(eq. 5)

$\mathrm{E}-$ flux $=\mathrm{Ec} * \mathrm{R}$

\section{RESULTS}

\section{Radioisotope profiles and chronologies}

The activity profiles of ${ }^{137} \mathrm{Cs},{ }^{210} \mathrm{~Pb}$ and ${ }^{226} \mathrm{Ra}$ are shown in Fig. 2 a,b. The first recognition of ${ }^{137} \mathrm{Cs}$ activity is at the mass depth of $9.1 \mathrm{~g} \mathrm{~cm}^{-2}$ in the Core $\mathrm{CH} 2012$, while the profile of ${ }^{137} \mathrm{Cs}$ shows a large and obvious peak at the mass depth of $8.6 \mathrm{~g} \mathrm{~cm}^{-2} \cdot{ }^{137} \mathrm{Cs}$ occurring in the year 1952 represents the beginning of atmospheric bomb testing, however, the ${ }^{137} \mathrm{Cs}$ activity was lower in the early stage. Considering diffusion and post depositional mobility of the radionuclide in sediments, the accuracy of the first ${ }^{137} \mathrm{Cs}$ occurring position is difficult to identify. Nevertheless, the influence of diffusion and diagenetic processes did not significantly change the position of the maximum peak of ${ }^{137} \mathrm{Cs}$ in sediments. Thus, the first obvious ${ }^{137} \mathrm{Cs}$ peak at the mass depth of $\sim 8.6 \mathrm{~g} \mathrm{~cm}^{-2}$ corresponds to $1963 \mathrm{AD}$, which is similar with the widely recognized peak caused by the global fall-out peak.

The ${ }^{210} \mathrm{~Pb}$ and ${ }^{226} \mathrm{Ra}$ activities generally reached equilibrium at the bottom of the sediment core, whereas the ${ }^{210} \mathrm{~Pb}_{\text {ex }}$ profile does not show exponential variations with the mass depth (Fig. 2b). Therefore, the CRS model might be more appropriate for the chronological models than the CIC model. As shown in Fig. 2c, the CRS model underestimated the age of the sediments: the CRS model provided a date of $1982 \mathrm{AD}$ at the mass depth of $8.6 \mathrm{~g} \mathrm{~cm}^{-2}$ in Core CH2012,

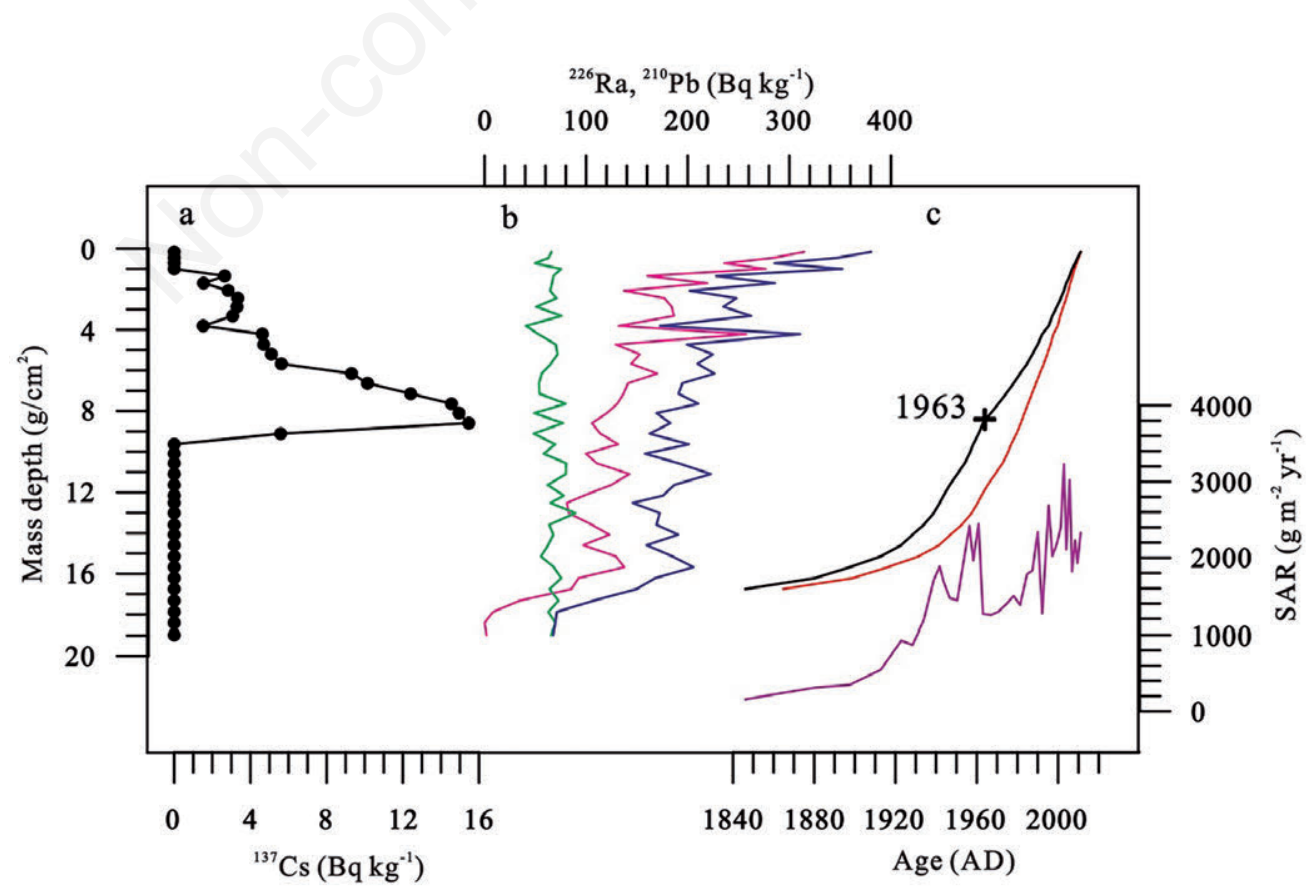

Fig. 2. Variations of (a) ${ }^{137} \mathrm{Cs}$, (b) ${ }^{226} \mathrm{Ra}$ (green line), ${ }^{210} \mathrm{~Pb}_{\text {tot }}$ (purple) and ${ }^{210} \mathrm{~Pb}$ ex (pink) activities, and (c) chronology (red line represents the CRS age model, and black one represents the compositional CRS age model) and SAR of Core CH2012. 
which deviated by $\sim 20$ years from the ${ }^{137} \mathrm{Cs}$ date. Thus, the composite model was chosen to develop the age-mass depth model (Fig. 2c). The basal age is about $1846 \mathrm{AD}$, and the SAR ranges from 157.7 to $3229.8 \mathrm{~g} \mathrm{~m}^{-2} \mathrm{yr}^{-1}$ (Fig. 2c).

\section{Physical and chemical properties of the sediment core}

The grain-size distributions from Lake Chenghai sediments are shown in Fig. 3a, and the data were characterized by asymmetrical distribution. The compositions of lithic particles of Lake Chenghai sediments are shown in Fig. 4. The sediments were mainly composed of silt, ranging from 73.0 to $93.5 \%$, with a mean of $77.7 \%$. The trend of the clay content was negatively correlated with silt because the sand fraction was extremely low in Lake Chenghai sediments, with a maximum of $1.5 \%$. The median values ranged from 4.0 to $9.6 \mu \mathrm{m}$, with a mean of $5.0 \mu \mathrm{m}$. The grain size $v s$. standard deviation plot shows that two sensitive grain-size components can be identified based on the two peaks of standard deviations in the curve at $2.2 \mu \mathrm{m}$ and $13.2 \mu \mathrm{m}$, their corresponding size ranges were $<5.0 \mu \mathrm{m}$ and $>5.0$ $\mu \mathrm{m}$ respectively (Fig. 3b). The content of coarser component fluctuated from 41.4 to 77.0 with a mean of 48.4, while the finer content of varied inversely with the coarser component (Fig. 4). The lithic composition remained relatively stable before $2003 \mathrm{AD}$, and then the content of coarser component significantly increased to the present (Fig. 4).

The concentrations of Ti generally increased from the bottom to $1952 \mathrm{AD}$, and then gradually decrease to the surface, ranging from 6.4 to $7.6 \mathrm{~g} \mathrm{~kg}^{-1}$ (Fig. 5). The

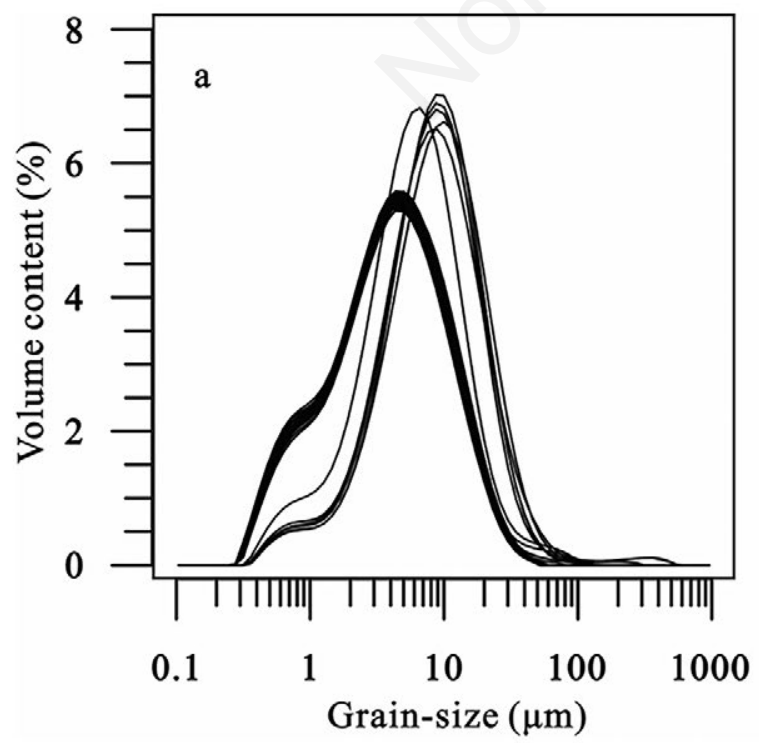

vertical changes of $\mathrm{Fe}$ and $\mathrm{Mn}$ concentrations were similar to that of the Ti profile, $\mathrm{Fe} / \mathrm{Mn}$ ratio varied inversely with Mn concentration, ranging from 59.1 to 66.8 with a mean of 62.0 (Fig. 5). Unlike the concentrations of terrigenous elements, the contents of TOC, TN and TP remained relatively stable before $1990 \mathrm{AD}$, and then significantly increased to the present (Fig. 5). The profile shows low organic carbon in the sediments, which varied between 0.9 and $4.7 \%$ (Fig. 5). The $\mathrm{C} / \mathrm{N}$ molar ratio ranged from 8.0 to 11.6 with a mean of 9.5 (Fig. 5). Ti flux and organic carbon burial rate revealed a generally increasing trend over the profile, ranging from 1.1 to $22.0 \mathrm{~g} \mathrm{~m}^{-2} \mathrm{yr}^{-1}$ and from 1.4 to $110.0 \mathrm{~g} \mathrm{~m}^{-2} \mathrm{yr}^{-1}$, with a relative high peak during the mid- $20^{\text {th }}$ century.

\section{DISCUSSION}

\section{Source of the siliciclastic materials}

Determined by the geographic location and geomorphological settings, detrital particles in Lake Chenghai sediments would be expected to be mainly derived from the hillsides transported by the precipitation and seasonal rivers during the rainy season and atmospheric dust deposits during the dry season. Previous studies suggest that the three types of clastic sediments exhibit different fractions of mixing of specific grain-size components due to distinct transport dynamics. Therefore, the grain-size composition is widely used to reflect the sources and transport processes of lacustrine sediments (Xiao et al., 2012; Dietze et al., 2014).

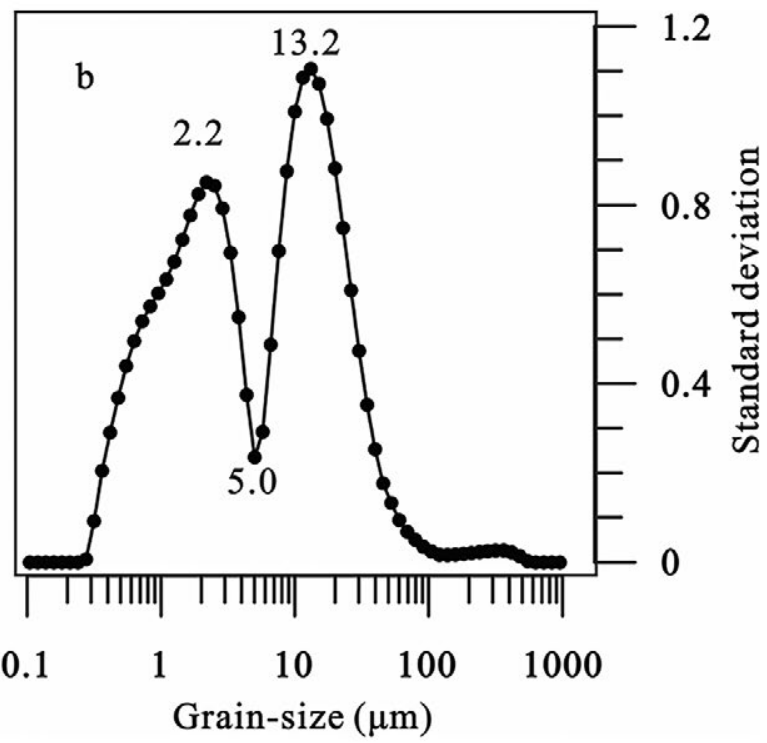

Fig. 3. (a) Grain-size distribution curves of Core $\mathrm{CH} 2012$; (b) Grain-size vs. standard deviation diagram of the grain-size analysis. 
Fluvial and alluvial sediments are mainly composed of saltation sand with dominant modal sizes of 100-400 $\mu \mathrm{m}$ or even coarser and suspended fine silt with dominant modal sizes of about 10-15 $\mu \mathrm{m}$ (Sun et al., 2002; Xiao et al., 2012). However, the grain-size distribution of fluvial component would be highly modified by high and low hydrodynamics during the deposition process in the lake (Finney and Johnson, 1991). In general, the saltation sand component occurs only in the littoral zone where shallow water possesses high energy, and its relative abundance decreases significantly as the water depth increases (Xiao et al., 2012). In Lake Chenghai, the coarser component with a dominant modal size of $13.2 \mu \mathrm{m}$, is consistent with the fine modal size of fluvial or alluvial source, implying that the component represents offshore suspended components. The coarser sands, however, are generally low in the lacustrine sediments, which might be related to the rapid changes of water depth and decrease of hydraulic conditions.

Primary aeolian sediments exhibit different fractions of mixing of specific grain-size components due to different sorting mechanisms during wind transport and deposition processes (Sun et al., 2002; Vandenberghe, 2013). Theoretically, particles that are larger than $70 \mu \mathrm{m}$ would be transported in the range of hundreds of meters or a few kilometers; the fraction of modal grain-size 10$70 \mu \mathrm{m}$ is transported by near-surface winds to a distance about $250 \mathrm{~km}$; and the fine-silt and clay fraction is mainly transported by upper-level air flow over relatively large distance (Tsoar and Pye, 1987; Sun et al., 2008).
Therefore, a number of categories of primary aeolian sediments with different grain-size distribution was identified: sediment with a model grain-size in the sand



Fig. 4. Variations in the median grain size, fractions of clay, silt, and sand as well as the coarser sensitive fraction derived from Grain-size vs. standard deviation method. The dashed line represents the year of $2001 \mathrm{AD}$ when the 6.0 magnitude earthquake occurred in Yongsheng County.



Fig. 5. Depth profiles of the selected chemical proxies in the Core CH2012, including concentrations of Fe, Mn, Ti, P, TOC, TN; element ratio of $\mathrm{Fe} / \mathrm{Mn}$ and original $\mathrm{C} / \mathrm{N}$ molar ratio; Ti flux and organic carbon burial rate. The assumed inorganic nitrogen corrected $\mathrm{C} / \mathrm{N}$ molar ratios are also shown in the figure (dashed line). 
fraction is dominant in marginal loess regions that represents the transition to desert or dune belts; the medium to coarse silt fraction is a typical component of the loess from the Chinese Loess Plateau, central Asia and Europe; sediment dominated by the fine silt and clay particles is well identified in Red Clays from the Chinese Loess Plateau, the northeast Qinghai-Tibetan Plateau and central Europe, but only presents in small amounts in most of the Quaternary loess (Vandenberghe, 2013). Similarly, the lakes near the dust source area would receive more sand fraction while the lakes in humid area are mainly influenced by fine dust. For example, Dietze et al. (2014) suggested that fine fraction had a mode between 2- $5 \mu \mathrm{m}$ over the Qinghai-Tibetan Plateau could be used to trace the remote dust deposits. In Lake Chenghai sediments, the finer component is similar to the dust component carried by the high-level westerlies, which indicates that the finer component might be of dust origin.

Globally, dust deposition rates are closely related to distance to source region (Lawrence and Neff, 2009). Assuming that the Ti concentration of aeolian dust equals to the mean concentration of $5 \mathrm{mg} / \mathrm{g}$, aeolian Ti deposition rates at sites located within or very near to primary source areas are estimated to range from 0.4 to $2.6 \mathrm{~g} \mathrm{~m}^{-2} \mathrm{yr}^{-1}$. While sites located further than $1000 \mathrm{~km}$ away from source regions receive less than $0.005 \mathrm{~g}$ Ti from the dust deposition per year (Lawrence and Neff, 2009). In Lake Chenghai, Ti flux rates of particles $<5 \mu \mathrm{m}$ ranged from 0.6 to $12.7 \mathrm{~g} \mathrm{~m}^{-2} \mathrm{yr}^{-1}$ with a mean of $6.0 \mathrm{~g} \mathrm{~m}^{-2} \mathrm{yr}^{-1}$, which was significant higher than the contemporary Ti flux rates from aeolian dust. One possible explanation is that the remote atmospheric dust can also be affected by postdepositional reworking, and the grain-size composition of primary dust did not change substantially by overland flow (Vandenberghe, 2013). Therefore, it is difficult to further distinguish transporting dynamics of the finer component in this study.

\section{Source of the organic matter}

Geochemical characteristics of lacustrine sediment organic matter are widely used to distinguish the contribution of terrestrial and aquatic vegetation (Meyers, 1997 and 2003). Generally, phytoplankton is typically marked by TOC/TN molar ratios between 4 and 10 due to the high protein/low carbohydrate content; submerged and floating aquatic macrophytes usually have TOC/TN ratios between 10 and 20. In contrast, TOC/TN ratios of vascular land plants often exceed 20 due to the high carbohydrate content (Meyers, 1997; Talbot and Lærdal, 2000). In Lake Chenghai sediment cores, the TOC/TN ratios range from 8.0 to 11.6 , with a mean of 9.2, distinctly isolated from that of the vascular terrestrial plants. The results are consistent with previous studies (Wan et al., 2005; Zan et al., 2012). The study of soils in the Yunnan
Province, however, showed that mean TOC/TN ratios was about 11.4 \pm 4.4 (Duan et al., 2014). The misleading indications of bulk organic matter origin can be caused by the typically measurement of the nitrogen contents that combines both organic nitrogen and inorganic nitrogen (Meyers, 1997). Regression of TOC versus TN in samples from the cores showed a strong linear relationship $\left(\mathrm{r}^{2}=\right.$ $0.99, \mathrm{P}<0.001$ ), with an intercept about 0.04 (Fig. 6). This suggests that the proportion of inorganic nitrogen can be a large fraction of the total nitrogen content in the case of sediments which have low organic matter content (Liu et al., 2010; Nara et al., 2014; Sun et al., 2016). After the simple correction by subtracting the intercept, although TOC/TN ratios significantly increased and ranged from 11.3 to 14.3 with a mean of 12.3 (Fig. 5), the ratios are still similar to that of aquatic-derived organic matter. Therefore, organic matter in Lake Chenghai sediment might derive from both of endogenous and exogenous material, but dominated by autochthonous material. The slightly higher TOC/TN ratios could also be attributed to preferentially degradation of proteic components during early diagenesis (Meyers, 1997; Talbot and Lærdal, 2000; Olsen et al., 2013).

\section{Response of soil erosion to environmental change}

As shown by the fluvial-Ti flux, the increasing trend of soil erosion in the catchment of Lake Chenghai compares well to the weakening of the Indian summer monsoon during the past 160 years (Fig. 7; Duan et al., 2004; Wang et al., 2005). Stable oxygen $\left(\delta^{18} \mathrm{O}\right)$ and

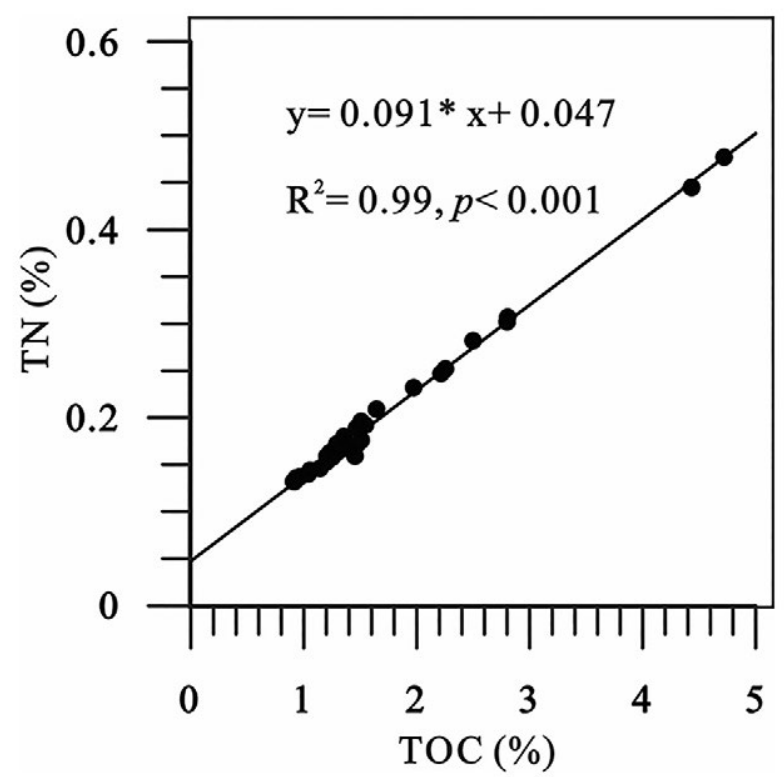

Fig. 6. Scatter plot of Core CH2012 sedimentary TOC versus TN. 
hydrogen $(\delta \mathrm{D})$ isotopes of precipitation in the Indian monsoon area have been widely used as one of the most reliable records representing summer monsoon intensity. Speleothem $\delta^{18} \mathrm{O}$ record from Dongge Cave in south China and tree ring $\delta^{18} \mathrm{O}$ and $\delta \mathrm{D}$ records from the Qinghai-Tibetan Plateau suggest that the Indian summer monsoon became progressively weaker since the late Little Ice Age (Fig.7e; Wang et al., 2005; Grießinger et al., 2011; Sano et al., 2012; Xu et al., 2012; An et al., 2014). A general decreasing trend of monsoonal precipitation over the past 160 years is also observed in the accumulation rate in the Dasuopu ice core and the varve thickness in Lake Xinluhai on the Tibetan Plateau, which are also monsoon precipitation record (Fig. 7c; Duan et al., 2004; Chu et al., 2011).

Heavy rainfall would enhance soil erosion over the lake catchment in arid region and increase the transport capacity of surface runoff (Liu et al., 2007). However, vegetation cover is also sensitive to precipitation in the arid/semi-arid environments, where wetter climatic conditions correspond to denser vegetation cover (Shen et al., 2013). Vegetation density controls both hydrological and mechanical properties of slope stability in mountain areas, that is denser vegetation cover, plants bind soil particles, to create bio-pores and form mechanical barriers for soil and water movement, resulting in less material transporting into the lakes (Gyssels and Poesen, 2003; Istanbulluoglu and Bras, 2005). During drier periods, reduced vegetation cover in the catchment exposes more soil superficial area, leading to even relatively low-intensity rainfall could create a stronger overland flow and more particles entering the lake (Gyssels and Poesen, 2003; Istanbulluoglu and Bras, 2005). In addition, increasing temperature after the Little Ice Age would enhance the rate of evaporation and reduce the effective humidity, and further suppress the growth of vegetation in the catchment (Mann et al., 1998).

The variation of lake surface area is suggested to be an important factor determining the flux and grain-size of siliciclastic materials in the lake, where small lake with small basin having higher sedimentation rates (Xu et al., 2017). The lake level of Lake Chenghai has gradually decreased about $30 \mathrm{~m}$ since the $19^{\text {th }}$ century due to the weakening of the Indian summer monsoon and increasing temperature (Fig. 7h; Ji, 2014). However, its east-west direction slopes are relatively large as it is formed by tectonic activity. The grain-size compositions of the sediments were generally stable until about 2003 AD, which might be related to the 6.0-magnitude earthquake occurred in 2001 in Yongsheng County considering the error in ${ }^{210} \mathrm{~Pb}$ dating. The effects of earthquake-triggered shaking on high and steep slopes in mountainous areas often lead to increase occurrences of secondary geohazards such as debris flows, landslides and the formation of unstable slopes, resulting more silt particles were transported into the lake by surface runoff (Schwab et al., 2009; Wilhelm et al., 2016). The general stable gain-size

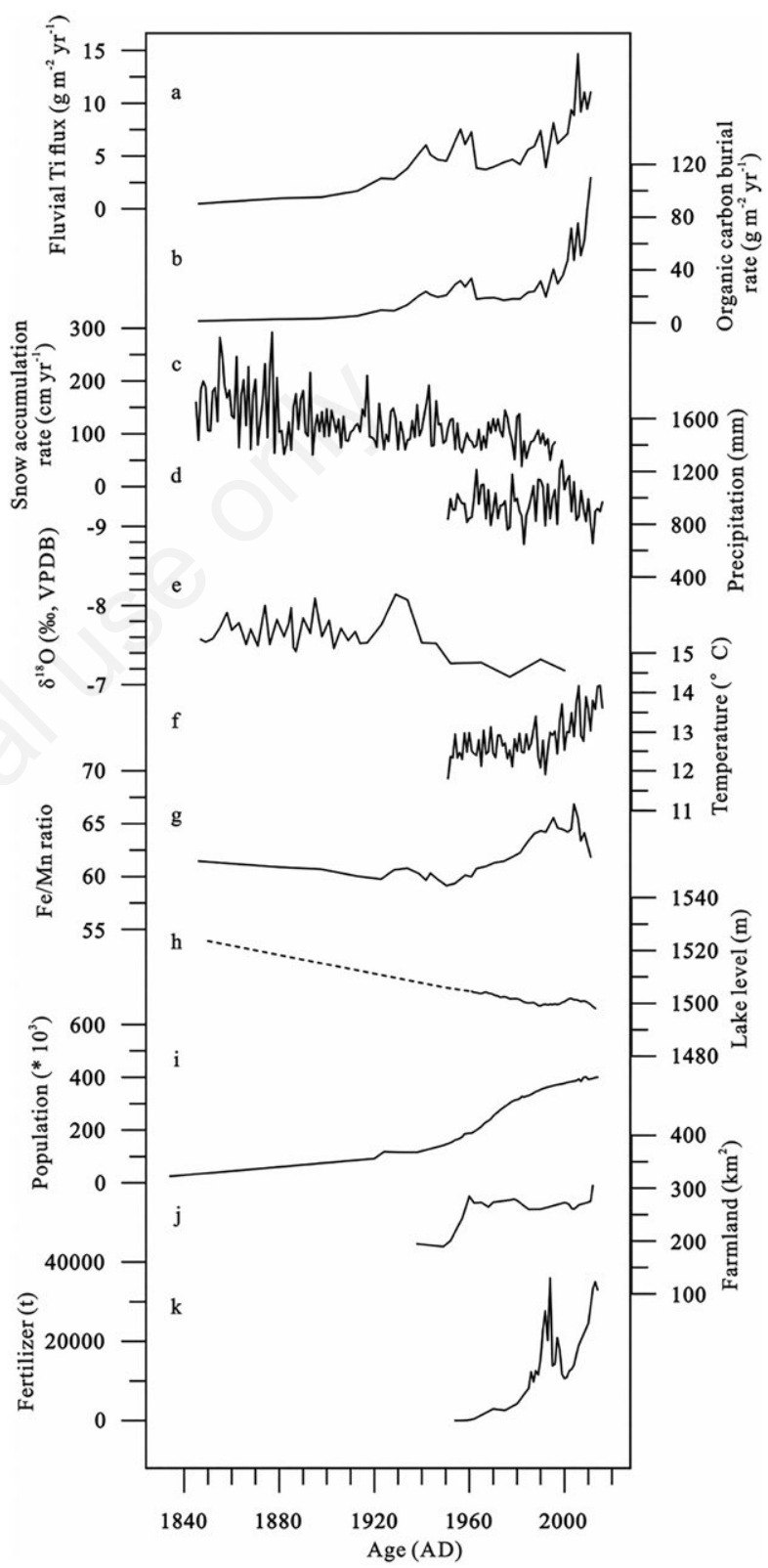

Fig. 7. Comparisons of (a) fluvial Ti flux and (b) organic carbon burial rate of Core $\mathrm{CH} 2012$ with other environmental proxies around Lake Chenghai. c) Snow accumulation rate of Dasuopu ice core in the QTP (Duan et al., 2004); d) precipitation data from Lijiang station (www.cma.gov.cn); e) stalagmite $\delta^{18} \mathrm{O}$ from Dongge Cave in South China (Wang et al., 2005), f) temperature data from Lijiang station (www.cma.gov.cn); g) Fe/Mn ratio of Core CH2012 (this study); h) variation of lake level of Lake Chenghai (the dashed line means the estimated values from historic record, Ji, 2014); i) population, j) cultivated area and fertilizer used in Yongsheng County. 
of sediments indicates that the variation of transporting distance from the lake shore to the deposition site was limited over the past 160 years. Therefore, the earthquake may increase the flux of siliciclastic materials in Lake Chenghai during the last decade and the lake size is assumed to have had only a minor effect on the flux of siliciclastic materials in Lake Chenghai.

In addition to environmental change, deforestation and expanded agricultural land use associated with human activities may also accelerate soil erosion in the catchment, resulting in reduced protective capacity of land cover for soils (Liu et al., 2007; Xu et al., 2017). The peak of the fluvial-Ti flux between 1930s and 1950s was mainly due to the agricultural development in the catchment. Since the $20^{\text {th }}$ century, the population settled in this region has continuously increased, and large scaled barren lands and woodland were reclaimed as farmland to increase agriculture yield during the first half of the $20^{\text {th }}$ century (Fig. 7 i,j; Yongsheng Statistics Bureau, 1986). The significant increase in arable land rate dated to 1949 in Yongsheng County demonstrated a large scaled land reclamation during the 1950s (Fig. 7j; Yongsheng Statistics Bureau, 1986). Then the arable land retained relatively stable in spite of the continuous increasing population during the past 50 years. This might be mainly due to the changed agricultural method to improve grain yield per unit area (Liu et al., 2007). Thus, the relative stable land use pattern during the last 50 years also appears to be an insignificant control on soil erosion than climate change.

\section{Implication for organic carbon burial in lacustrine sediment}

Our study showed an increasing trend in organic carbon burial in Lake Chenghai over the past 160 years, particularly during the last three decades (Fig. 7b). This phenomenon has been widely found in most lakes in China and other parts of the world. The weighted mean burial rate of organic carbon in Lake Chenghai during this period is only about $15.1 \mathrm{~g} \mathrm{~m}^{-2} \mathrm{yr}^{-1}$, which is much lower than the estimate of $24.3 \mathrm{~g} \mathrm{~m}^{-2} \mathrm{yr}^{-1}$ in the lake sediments of the Yunnan-Guizhou Plateau Lake Region, $30.6 \mathrm{~g} \mathrm{~m}^{-2} \mathrm{yr}^{-1}$ of the Eastern Plain Lake Region, $30.4 \mathrm{~g} \mathrm{~m}^{-2} \mathrm{yr}^{-1}$ of the Inner Mongolian-Xinjiang Lake Region, and $25.4 \mathrm{~g} \mathrm{~m}^{-2} \mathrm{yr}^{-1}$ of the Northeast Mountain and Plain Lake Region, but similar to that of the Tibet Plateau Lake Region $\left(14.3 \mathrm{~g} \mathrm{~m}^{-2} \mathrm{yr}^{-1}\right)$ in China (Zhang F. et al., 2017). On the global scale, even larger magnitude variation of organic carbon burial rate in the lake and reservoir sediments was observed (from 0.2 to about $17,400 \mathrm{~g} \mathrm{~m}^{-2} \mathrm{yr}^{-1}$ ), with high values in small agricultural ponds and artificial reservoirs (Mendonça et al., 2017). This is mainly due to the differences in geographical location, land use in the catchment, nutrient input and limnological parameters.

On the long-term scale, the organic matter burial rates were mainly determined by catchment disturbance. Changes in terrestrial sediment delivery can influence lacustrine organic carbon burial in several processes (von Wachenfeldt and Tranvik, 2008; Sobek et al., 2009; Tranvik et al., 2009; Dietz et al., 2015). First, elevated sediment delivery via erosion would enhance terrestrial carbon loading to the lake environment (Dietz et al., 2015). The increasing TOC/TN molar ratio before 1960 $\mathrm{AD}$ was consistent with the trend of fluvial-Ti flux, indicating that increasing soil organic matter was transported to the lake. Then the relative low TOC/TN molar ratio of sediments might be determined by the gradual eutrophication of Lake Chenghai which significantly enhanced aquatic primary productivity (Zan et al., 2012). Furthermore, mineral grains may increase the transport of organic matter from surface waters to lake floor, assuming that organic flocculates bind to suspended inorganic particulates or sinking particles scavenge organic material from the water column (von Wachenfeldt and Tranvik, 2008). In addition, higher flux of siliciclastic materials may also increase organic carbon burial efficiency, elevated sedimentation lead to quicker isolation of deposited organic material from the sediment surface, reducing the duration of its exposure to oxygen and the possibility of resuspension into oxic zones (von Wachenfeldt and Tranvik, 2008; Sobek et al., 2009).

Climate-related variables and eutrophication can further modify organic carbon burial patterns through their influence on primary productivity and burial efficiency. Although higher temperature favors higher rate of decomposition of organic matter in the water column (Gudasz et al., 2010), eutrophication might elevate the aquatic primary productivity, leading to increased TOC content at lakes (Cook et al., 2012; Shen et al., 2005). The rapid rise of TOC content and burial rate in Lake Chenghai sediment since the late 1980s was consistent with the period of widespread use of commercial fertilizers (Fig. 7k), discharge of wastewater and artificial cultivation of Spirulina (Zan et al., 2012). Furthermore, changing bottom water oxygen concentration caused by climate change and eutrophication might also influence post-depositional diagenesis of the organic matter. Fe/ $\mathrm{Mn}$ ratio has been used to reflect changing redox conditions in lakes, due to more rapid reduction of $\mathrm{Mn}$ than $\mathrm{Fe}$ under anoxic conditions (Naeher et al., 2013; Zhu et al., 2009). Higher Fe/Mn ratio indicated lower $\mathrm{O}_{2}$ concentrations in the bottom water, while lower ratio occurs under oxic conditions. The decreasing $\mathrm{O}_{2}$ concentrations in the bottom water were closely related to the drop of lake level in oligotrophic status before $1950 \mathrm{AD}$, resulting in more degradation of the organic matter (Fig. $7 \mathrm{~g}$ ). In contrast, increased primary productivity and therefore $\mathrm{O}_{2}$ consumption during organic matter mineralization in deeper water would lead to a stronger release of Mn compared to Fe from the sediment- 
water interface (Fig. 7g). Although lacustrine sediments are efficient at burying organic carbon, some recent studies showed that a considerable fraction of organic matter in the sediments which are younger than 5-10 years would be mineralized prior to long-term burial (Galman et al., 2008; Sobek et al., 2009). Post-depositional mineralization is largely controlled by organic matter contact with $\mathrm{O}_{2}$ (Anderson et al., 2014). The anoxia condition caused by eutrophication can lead to reduced $\mathrm{O}_{2}$ exposure time and thus less degradation of post-depositional organic matter in Lake Chenghai. Therefore, Lake Chenghai may play a more important role in terrestrial carbon cycling under eutrophic status.

\section{CONCLUSIONS}

A sediment core (CH2012) spanning the last 160 years was retrieved from Lake Chenghai in southwest China in order to investigate the response of catchment soil erosion and organic carbon burial to climate change. The result of grain-size $v s$. standard deviation method shows that the lacustrine deposits contain two sensitive fractions with a modal size of 13.2 and $2.2 \mu \mathrm{m}$ respectively, and coarser fractions with the modal size of $13.2 \mu \mathrm{m}$ is related to fluvial processes and sensitive to the soil erosion in the catchment. The increasing intensity of soil erosion is mainly determined by the weakening of the Indian summer monsoon and global warming, which resulted in decreased vegetation cover and reduced soil cohesion. Intensive human activities such as deforestation and land reclamation during the mid- $20^{\text {th }}$ century might also induce soil loss in Lake Chenghai catchment. The organic carbon burial rate increased from $1.4 \mathrm{~g} \mathrm{~m}^{-2} \mathrm{yr}^{-1}$ in the late $19^{\text {th }}$ century to 110.0 $\mathrm{g} \mathrm{m}^{-2} \mathrm{yr}^{-1}$ at the present. The large magnitude variation in organic carbon burial rate is attributed to the catchment disturbance, although climate change and eutrophication can further modify organic carbon burial patterns.

\section{ACKNOWLEDGMENTS}

The research was supported by the found from State Key Laboratory of Lake Science and Environment (2016SKL003), the National Basic Technological Research of China (No. 2014FY110400), and the National Natural Science Foundation of China (Grants 41702183 and 41271214).

\section{REFERENCES}

An W, Liu X, Leavitt S, Xu G, Zeng X, Wang W, Qin D, Ren J, 2014. Relative humidity history on the Batang-Litang Plateau of western China since 1755 reconstructed from tree-ring $\delta^{18} \mathrm{O}$ and $\delta \mathrm{D}$. Clim. Dynam. 42:2639-2654.
Anderson NJ, Bennion H, Lotter AF, 2014. Lake eutrophication and its implications for organic carbon sequestration in Europe. Glob. Change Biol. 20:2741- 2751.

Appleby PG, 2001. Chronostratigraphic techniques in recent sediments, p. 171-203. In: W. Last and J. Smol (eds.), Tracking environmental change using lake sediments. Springer, Dordrecht.

Barton AP, Fullen MA, Mitchell DJ, Hocking TJ, Liu L, Wu BZ, Zheng Y, Xia ZY, 2004. Effects of soil conservation measures on erosion rates and crop productivity on subtropical Ultisols in Yunnan Province, China. Agr. Ecosyst. Environ. 104:343-357.

Chen F, Qiang M, Zhou A, Xiao S, Chen J, Sun D, 2013. A 2000-year dust storm record from Lake Sugan in the dust source area of arid China. J. Geophys. Res-Atmos. 118:2149-2160.

Chen HF, Yeh PY, Song SR, Hsu SC, Yang TN, Wang Y, Chi Z, Lee TQ, Chen MT, Cheng CL, Zou J, Chang YP, 2013. $\mathrm{The} \mathrm{Ti} / \mathrm{Al}$ molar ratio as a new proxy for tracing sediment transportation processes and its application in aeolian events and sea level change in East Asia. J. Asian Earth Sci. 73:31-38.

Chu G, Sun Q, Gu Z, Partrick RG, Liu QL, Wang K, Han J, Liu J, 2009. Dust records from varved lacustrine sediments of two neighboring lakes in northeastern China over the last 1400 years. Quatern. Int. 194:108-118.

Chu G, Sun Q, Yang K, Li A, Yu X, Xu T, Yan F, Wang H, Liu M, Wang X, Xie M, Lin Y, Liu Q, 2011. Evidence for decreasing South Asian summer monsoon in the past 160 years from varved sediment in Lake Xinluhai, Tibetan Plateau. J. Geophys. Res-Atmos. 116:D02116.

Cole JJ, Prairie YT, Caraco NF, McDowell WH, Tranvik LJ, Striegl RG, Duarte CM, Kortelainen P, Downing JA, Middelburg JJ, Melack J, 2007. Plumbing the global carbon cycle: integrating inland waters into the terrestrial carbon budget. Ecosystems 10:172-185.

Cook CG, Leng MJ, Jones RT, Langdon PG, Zhang E, 2012. Lake ecosystem dynamics and links to climate change inferred from a stable isotope and organic palaeorecord from a mountain lake in southwestern China (ca. 22.6-10.5 cal ka BP). Quaternary Res.77:132-137.

Dearing JA, Battarbee RW, Dikau R, Larocque I, Oldfield F, 2006. Human-environment interactions: learning from the past. Reg. Environ. Change 6:1-16.

Dietz RD, Engstrom DR, Anderson NJ, 2015. Patterns and drivers of change in organic carbon burial across a diverse landscape: Insights from 116 Minnesota lakes. Global Biogeochem. Cy. 29:708-727.

Dietze E, Hartmann K, Diekmann B, Ijmker J, Lehmkuhl F, Opitz S, Stauch G, Wünnemann B, Borchers A, 2012. An end-member algorithm for deciphering modern detrital processes from lake sediments of Lake Donggi Cona, NE Tibetan Plateau, China. Sediment. Geol. 243-244:169-180.

Dietze E, Maussion F, Ahlborn M, Diekmann B, Hartmann K, Henkel K, Kasper T, Lockot G, Opitz S, Haberzettl T, 2014. Sediment transport processes across the Tibetan Plateau inferred from robust grain-size end members in lake sediments. Clim. Past. 10:91-106.

Duan K, Yao T, Thompson LG, 2004. Low-frequency of southern Asian monsoon variability using a 295-year record 
from the Dasuopu ice core in the central Himalayas. Geophys. Res. Lett. 31:L16209.

Duan X, Rong L, Hu J, Zhang G, 2014. Soil organic carbon stocks in the Yunnan Plateau, southwest China: spatial variations and environmental controls. J. Soil. Sediment. 14:1643-1658.

Dudgeon D, Arthington AH, Gessner MO, Kawabata ZI, Knowler DJ, Lévêque C, Naiman RJ, Prieur-Richard AH, Soto D, Stiassny MLJ, Sullivan CA, 2006. Freshwater biodiversity: importance, threats, status and conservation challenges. Biol. Rev. 81:163-182.

Finney BP, Johnson TC, 1991. Sedimentation in Lake Malawi (East Africa) during the past 10,000 years: a continuous paleoclimatic record from the southern tropics. Palaeogeogr. Palaeoecl. 85:351-366.

Galman V, Rydberg J, de-Luna SS, Bindler R, Renberg I, 2008. Carbon and nitrogen loss rates during aging of lake sediment: changes over 27 years studied in varved lake sediment. Limnol. Oceanogr. 53:1076-1082.

Grießinger J, Bräuning A, Helle G, Thomas A, Schleser G, 2011. Late Holocene Asian summer monsoon variability reflected by $\delta^{18} \mathrm{O}$ in tree-rings from Tibetan junipers. Geophys. Res. Lett. 38:L03701.

Gudasz C, Bastviken D, Steger K, Premke K, Sobek S, Tranvik LJ, 2010. Temperature-controlled organic carbon mineralization in lake sediments. Nature 466:478-481.

Gyssels G, Poesen J, 2003. The importance of plant root characteristics in controlling concentrated flow erosion rates. Earth Surf. Proc. Land. 28:371-384.

Istanbulluoglu E, Bras RL, 2005. Vegetation-modulated landscape evolution: Effects of vegetation on landscape processes, drainage density, and topography. J. Geophys. Res- Earth Surf. 110:F02012. doi:10.1029/2004JF000249.

Ji K, 2014. [Variation of the lake level of Lake Chenghai in the history and its influcing factors].[Article in in Chinese]. Proceedings of the 4th Workshop for Chinese Lakes, Hefei, China.

Krinner G, 2003. Impact of lakes and wetlands on boreal climate. J. Geophys. Res-Atmos. 108:4520.

Lawrence CR, Neff JC, 2009. The contemporary physical and chemical flux of aeolian dust: A synthesis of direct measurements of dust deposition. Chem. Geol. 267:46-63.

Liu E, Shen J, Zhang E, Wu Y, Yang L, 2010. A geochemical record of recent anthropogenic nutrient loading and enhanced productivity in Lake Nansihu, China. J. Paleolimnol. 44:15-24.

Liu E, Yang X, Shen J, Dong X, Zhang E, Wang S, 2007. Environmental response to climate and human impact during the last 400 years in Taibai Lake catchment, middle reach of Yangtze River, China. Sci. Total Environ. 385:196-207.

Liu J, Diamond J, 2005. China's environment in a globalizing world. Nature 435:1179-1186.

Liu J, Lü H, Negendank J, Mingram J, Luo X, Wang W, Chu G, 2000. Periodicity of Holocene climatic variations in the Huguangyan Maar Lake. Chinese Sci. Bull. 45:1712-1717.

Liu X, Dong H, Yang X, Herzschuh U, Zhang E, Stuut JBW, Wang Y, 2009. Late Holocene forcing of the Asian winter and summer monsoon as evidenced by proxy records from the northern Qinghai-Tibetan Plateau. Earth Planet Sc. Lett. 280:276-284.
Mann ME, Bradley RS, Hughes MK, 1998. Global-scale temperature patterns and climate forcing over the past six centuries. Nature 392:779-787.

Mendonça R, Müller RA, Clow D, Verpoorter C, Raymond P, Tranvik LJ, Sobek S, 2017. Organic carbon burial in global lakes and reservoirs. Nat. Commun. 8:1694.

Meyers PA, 1997. Organic geochemical proxies of paleoceanographic, paleolimnologic, and paleoclimatic processes. Org. Geochem. 27:213-250.

Meyers PA, 2003. Applications of organic geochemistry to paleolimnological reconstructions: a summary of examples from the Laurentian Great Lakes. Org. Geochem. 34:261-289.

Naeher S, Gilli A, North RP, Hamann Y, Schubert CJ, 2013. Tracing bottom water oxygenation with sedimentary $\mathrm{Mn} / \mathrm{Fe}$ ratios in Lake Zurich, Switzerland. Chem. Geol. 352:125-133.

Nara FW, Watanabe T, Kakegawa T, Minoura K, Imai A, Fagel N, Horiuchi K, Nakamura T, Kawai T, 2014. Biological nitrate utilization in south Siberian lakes (Baikal and Hovsgol) during the Last Glacial period: the influence of climate change on primary productivity. Quaternary Sci. Rev. 90:69-79.

Neff JC, Ballantyne AP, Farmer GL, Mahowald NM, Conroy JL, Landry CC, Overpeck JT, Painter TH, Lawrence CR, Reynolds RL, 2008. Increasing eolian dust deposition in the western United States linked to human activity. Nature Geosci. 1:189-195.

Olsen J, Anderson NJ, Leng MJ, 2013. Limnological controls on stable isotope records of late-Holocene palaeoenvironment change in SW Greenland: a paired lake study. Quaternary Sci. Rev. 66:85-95.

Rose NL, Morley D, Appleby PG, Battarbee RW, Alliksaar T, Guilizzoni P, Jeppesen E, Korhola A, Punning JM, 2011. Sediment accumulation rates in European lakes since AD 1850: trends, reference conditions and exceedence. J. Paleolimnol. 45:447-468.

Sano M, Ramesh R, Sheshshayee M, Sukumar R, 2012. Increasing aridity over the past 223 years in the Nepal Himalaya inferred from a tree-ring $\delta 180$ chronology. Holocene 22:809-817.

Schwab MJ, Werner P, Dulski P, McGee E, Nowaczyk NR, Bertrand S, Leroy SAG, 2009. Palaeolimnology of Lake Sapanca and identification of historic earthquake signals, Northern Anatolian Fault Zone (Turkey). Quaternary Sci. Rev. 28:991-1005.

Seddon AWR, Mackay AW, Baker AG, Birks HJB, Breman E, Buck CE, Ellis EC, Froyd CA, Gill JL, Gillson L, Johnson EA, Jones VJ, Juggins S, Macias-Fauria M, Mills K, Morris JL, Nogués-Bravo D, Punyasena SW, Roland TP, Tanentzap AJ, Willis KJ, Aberhan M, van Asperen EN, Austin WEN, Battarbee RW, Bhagwat S, Belanger CL, Bennett KD, Birks HH, Bronk Ramsey C, Brooks SJ, de Bruyn M, Butler PG, Chambers FM, Clarke SJ, Davies AL, Dearing JA, Ezard THG, Feurdean A, Flower RJ, Gell P, Hausmann S, Hogan EJ, Hopkins MJ, Jeffers ES, Korhola AA, Marchant R, Kiefer T, Lamentowicz M, Larocque-Tobler I, LópezMerino L, Liow LH, McGowan S, Miller JH, Montoya E, Morton O, Nogué S, Onoufriou C, Boush LP, RodriguezSanchez F, Rose NL, Sayer CD, Shaw HE, Payne R, Simpson G, Sohar K, Whitehouse NJ, Williams JW, Witkowski A, 2014. Looking forward through the past: 
identification of 50 priority research questions in palaeoecology. J. Ecol. 102:256-267.

Shen J, Liu X, Wang S, Ryo M, 2005. Palaeoclimatic changes in the Qinghai Lake area during the last 18,000 years. Quatern. Int. 136:131-140.

Shen J, Wu X, Zhang Z, Gong W, He T, Xu X, Dong H, 2013. Ti content in Huguangyan maar lake sediment as a proxy for monsoon-induced vegetation density in the Holocene. Geophys. Res. Lett. 40:5757-5763.

Sobek S, Durisch-Kaiser E, Zurbrügg R, Wongfun N, Wessels M, Pasche N, Wehrli B, 2009. Organic carbon burial efficiency in lake sediments controlled by oxygen exposure time and sediment source. Limnol. Oceanogr. 54:2243-2254.

Su Z, Xiong D, Dong Y, Li J, Yang D, Zhang J, He G, 2014. Simulated headward erosion of bank gullies in the Dry-hot Valley Region of southwest China. Geomorphology 204:532-541.

Sun D, Bloemendal J, Rea DK, Vandenberghe J, Jiang F, An Z, $\mathrm{Su}$ R, 2002. Grain-size distribution function of polymodal sediments in hydraulic and aeolian environments, and numerical partitioning of the sedimentary components. Sediment. Geol. 152:263-277.

Sun D, Su R, Bloemendal J, Lu H, 2008. Grain-size and accumulation rate records from Late Cenozoic aeolian sequences in northern China: Implications for variations in the East Asian winter monsoon and westerly atmospheric circulation. Palaeogeogr. Palaeocl. 264:39-53.

Sun W, Shen J, Zhang E, Hasebe N, Kashiwaya K, Chen R, Itono T, 2016. Stable nitrogen isotope record of lacustrine sediments in Lake Onuma (Northern Japan) indicates regional hydrological variability during the past four centuries. Quatern. Int. 397:307-316.

Sun Y, Gao S, Li J, 2003. Preliminary analysis of grain-size populations with environmentally sensitive terrigenous components in marginal sea setting. Chinese Sci. Bull. 48:184-187.

Talbot M, Lærdal T, 2000. The Late Pleistocene - Holocene palaeolimnology of Lake Victoria, East Africa, based upon elemental and isotopic analyses of sedimentary organic matter. J. Paleolimnol. 23:141-164.

Tranvik LJ, Downing JA, Cotner JB, Loiselle SA, Striegl RG, Ballatore TJ, Dillon P, Finlay K, Fortino K, Knoll LB, Kortelainen PL, Kutser T, Larsen S, Laurion I, Leech DM, McCallister SL, McKnight DM, Melack JM, Overholt E, Porter JA, Prairie Y, Renwick WH, Roland F, Sherman BS, Schindler DW, Sobek S, Tremblay A, Vanni MJ, Verschoor AM, von Wachenfeldt E, Weyhenmeyer GA, 2009. Lakes and reservoirs as regulators of carbon cycling and climate. Limnol. Oceanogr. 54:2298-2314.

Tsoar H, Pye K, 1987. Dust transport and the question of desert loess formation. Sedimentology 34:139-153.

Vandenberghe J, 2013. Grain size of fine-grained windblown sediment: A powerful proxy for process identification. Earth-Sci. Rev. 121:18-30.

Vanmaercke M, Poesen J, Govers G, Verstraeten G, 2015. Quantifying human impacts on catchment sediment yield: A continental approach. Global Planet Change 130:22-36.

von Wachenfeldt E, Tranvik LJ, 2008. Sedimentation in Boreal Lakes - The role of flocculation of allochthonous dissolved organic matter in the water column. Ecosystems 11:803-814.
Wan GJ, Chen JA, Wu FC, Xu SQ, Bai ZG, Wan EY, Wang CS, Huang RG, Yeager KM, Santschi PH, 2005. Coupling between ${ }^{210} \mathrm{~Pb}_{\text {ex }}$ and organic matter in sediments of a nutrient-enriched lake: An example from Lake Chenghai, China. Chem. Geol. 224:223-236.

Wang S, Dou H, 1998. [Lakes in China].[Book in Chinese]. Science Press, Beijing.

Wang X, Yang H, Ding Z, Yang B, Zhang M, 2011a. [Modern sedimentation rates of Fuxian Lake by ${ }^{210} \mathrm{~Pb}$ and ${ }^{137} \mathrm{Cs}$ dating].[Article in Chinese with English abstract]. Acta Geographica Sinica 66.1551-1561.

Wang X, Yang H, Zhao Q, Chen Y, Chen J, Wang L, 2011 b. [Modern sedimentation rates and dry-humid change inferred from grain size records in Dianchi Lake, Yunnan Province].[Article in Chinese with English abstract]. Geograph. Res. 30:161-171.

Wang Y, Cheng H, Edwards RL, He Y, Kong X, An Z, Wu J, Kelly MJ, Dykoski CA, Li X, 2005. The Holocene Asian monsoon: links to solar changes and North Atlantic climate. Science 308:854-857.

Wilhelm B, Nomade J, Crouzet C, Litty C, Sabatier P, Belle S, Rolland Y, Revel M, Courboulex F, Arnaud F, Anselmetti FS, 2016. Quantified sensitivity of small lake sediments to record historic earthquakes: Implications for paleoseismology. J. Geophys. Res-Earth Surf. 121:2-16.

Wu J, Gagan MK, Jiang X, Xia W, Wang S, 2004. Sedimentary geochemical evidence for recent eutrophication of Lake Chenghai, Yunnan, China. J. Paleolimnol. 32:85-94.

Xiao J, Chang Z, Fan J, Zhou L, Zhai D, Wen R, Qin X, 2012. The link between grain-size components and depositional processes in a modern clastic lake. Sedimentology 59:1050-1062.

Xiao J, Si B, Zhai D, Itoh S, Lomtatidze Z, 2008. Hydrology of Dali Lake in central-eastern Inner Mongolia and Holocene East Asian monsoon variability. J. Paleolimnol. 40:519-528.

$\mathrm{Xu} \mathrm{H}$, Hong Y, Hong B, 2012. Decreasing Asian summer monsoon intensity after $1860 \mathrm{AD}$ in the global warming epoch. Clim. Dynam. 39:2079-2088.

Xu M, Dong X, Yang X, Chen X, Zhang Q, Liu Q, Wang R, Yao M, Davidson T, Jeppesen E, 2017. Recent sedimentation rates of shallow lakes in the middle and lower reaches of the Yangtze River: Patterns, controlling factors and implications for lake management. Water 9:617.

Xue B, Yao S, 2011. Recent sedimentation rates in lakes in lower Yangtze River basin. Quatern. Int. 244:248-253.

Yancheva G, Nowaczyk NR, Mingram J, Dulski P, Schettler G, Negendank JFW, Liu J, Sigman DM, Peterson LC, Haug $\mathrm{GH}, 2007$. Influence of the intertropical convergence zone on the East Asian monsoon. Nature 445:74-77.

Yang S, Ding F, Ding Z, 2006. Pleistocene chemical weathering history of Asian arid and semi-arid regions recorded in loess deposits of China and Tajikistan. Geochim. Cosmochim. Ac. 70:1695-1709.

Yongsheng Statistics Bureau, 1986. [Local Chronicles of Yongsheng Country].[In Chinese].

Yu SY, Colman SM, Li L, 2016. BEMMA: A hierarchical Bayesian end-member modeling analysis of sediment grainsize distributions. Math. Geosci. 48:723-741.

Yu Z, Wang X, Zhao C, Lan H, 2015. Carbon burial in Bosten 
Lake over the past century: Impacts of climate change and human activity. Chem. Geol. 419:132-141.

Zan F, Huo S, Xi B, Zhang J, Liao H, Wang Y, Yeager KM, 2012. A 60-year sedimentary record of natural and anthropogenic impacts on Lake Chenghai, China. J. Environ. Sci. 24:602-609.

Zhang E, Tang H, Cao Y, Langdon P, Wang R, Yang X, Shen J, 2013. The effects of soil erosion on chironomid assemblages in Lugu Lake over the past 120 years. Int. Rev. Hydrobiol. 98:165-172.

Zhang E, Zhao C, Xue B, Liu Z, Yu Z, Chen R, Shen J, 2017.
Millennial-scale hydroclimate variations in southwest China linked to tropical Indian Ocean since the Last Glacial Maximum. Geology 45:435.

Zhang F, Yao S, Xue B, Lu X, Gui Z, 2017. Organic carbon burial in Chinese lakes over the past 150 years. Quatern. Int. 438:94-103.

Zhu L, Zhen X, Wang J, Lü H, Xie M, Kitagawa H, Possnert G, 2009. A 30,000-year record of environmental changes inferred from Lake Chen Co, Southern Tibet. J. Paleolimnol. 42:343-358. 